\title{
DNAJB6 Gene
}

National Cancer Institute

\section{Source}

National Cancer Institute. DNAIB6 Gene. NCI Thesaurus. Code C102930.

This gene is involved in protein chaperone activity. 